\title{
Kuraklık Stresine Dayanıklı Nohut Genotiplerinin Geliştirilmesi

\begin{tabular}{|c|c|c|c|c|}
\hline Derya YÜCEL ${ }^{1 \& 9}$ & Dürdane MART ${ }^{1}$ & Meltem TÜRKERİ ${ }^{1}$ & Nigar ANGIN¹ & Celal YÜCEL ${ }^{1}$ \\
\hline
\end{tabular}

Geliş (Received): 04.11.2017

Kabul (Accepted): 15.12.2017

\begin{abstract}
ÖZET: Nohut (Cicer arietinum L.), tanelerinin oldukça yüksek düzeyde protein içermesi, özellikle az gelişmiş veya gelişmekte olan ülkelerde gelir düzeyinin düşüklüğü nedeni ile yeterince hayvansal ürün tüketemeyen insanlar için önemli bir besin maddesidir. Bu projenin amacı, Ülkemizde son yıllarda geliştirilmiş ve yaygın olarak tarımı yapılan bazı nohut çeşitleri ile bölgemizde uzun yıllar yapılan çalışmalarda tane verimi bakımından öne çıkmış genotiplerin, kuraklık stresine toleranslı1ıklarını belirlemektir. Araştırmada 34 nohut genotipinde, çiçeklenmeye kadar geçen gün sayısı, bakla bağlamaya kadar geçen gün sayısı, bitki boyu, ilk bakla yüksekliği, yüz tane ağırlığı ve tane verimi incelenmiştir. Araştırma, tesadüf bloklarında faktöriyel deneme desenine göre 3 tekrarlamalı olarak Doğu Akdeniz Tarımsal Araştırma Enstitüsü deneme alanında yürütülmüştür. Çalışma üç farklı yetiştirme koşulunda (Kışlık ekim, Sulamalı Geç Ekim ve Sulamasız Geç Ekim), 2015-2016 yetiştirme sezonunda ekilmiştir. Her parsel, 4 m uzunluğunda iki sıradan oluşmakta, sıra arası $45 \mathrm{~cm}$ sabit tutularak her sıraya 60 tohum gelecek şekilde markör izine elle ekilmiştir. Sonuç olarak, araştırmada yer alan Aksu, Arda, Çakır, İnci ve Hasanbey çeşitleri kuraklık stresine toleranslılık bakımından öne çıkan çeşitler olmuştur. Ayrıca, EN 952, ENA 144-10, ENA 8-2, F4 09 (X 05 TH 21 16189-12-4), F4 09 (X 05 TH 80-16105-31-2) FLIP 03-21 C, EN 766, FLIP 03-108 C, ve FLIP 05-150 C hatlarının da ileride yapılacak kuraklık stres çalışmalarında değerlendirilebileceği sonucu elde edilmiştir.

Anahtar Kelimeler: Nohut, Abiyotik Stres, Toleranslılık ve Verimlilik
\end{abstract}

\section{Developing Drought Stress Tolerant Chickpea Genotypes}

ABSTRACT: Chickpea (Cicer arietinum L.) with high protein content is a vital food, especially in under-developed and developing countries for the people who do not consume enough meat due to low income level. The objective of this research is to determine tolerance of chickpea genotypes commonly grown and recently developed chickpea cultivars in TURKEY and commonly grown also genotypes came into prominence in our region against drought stress. For this purpose, a total of 34 chickpea genotypes were investigated in terms of days to flowering, days to podding, plant height, first pod height, 100 seed weight and seed yield. The experiments were conducted according to randomized complete block factorial design with 3 replications at the Eastern Mediterranean Research Institute in 2015-16 growing season. In this study three different growing conditions (winter sowing, irrigated-late sowing and non-irrigated- late sowing) were used. Each plot is going to consist 2 rows with $4 \mathrm{~m}$ long. There was $45 \mathrm{~cm}$ between two rows, and 60 plants per row. As a result, Aksu, Arda, Çakır, İnci and Hasanbey varieties can be suggested to drought stressed cultivars. Besides EN 952, ENA 144-10, ENA 8-2, F4 09 (X 05 TH 21 16189-12-4), F4 09 (X 05 TH 80-16105-31-2), FLIP 03-21 C, EN 766, FLIP 03-108 C, and FLIP 05-150 C lines can be evaluated for future researches.

Key Words: Chickpea, Drought Stress and Yield

\section{GíRiș}

Çalışma konusunu oluşturan nohut (Cicer arietinum L.), baklagiller (leguminosae) familyasından tek yıllık bir bitki olup, özellikle az gelişmiş veya gelişmekte olan ülkelerde gelir düzeyinin düşüklüğü nedeni ile yeterince hayvansal ürün tüketemeyen insanlar için önemli bir gıda maddesidir (Şehirali, 1988). Son yıllarda biyotik ve abiyotik stres faktörlerinin bitkisel üretimi olumsuz etkilemesi, bilim insanlarını olası iklim değişikliğinin olumsuz etkilerini azaltmak konusunda yeni önlemler almaya yönlendirmiştir (Yücel ve ark. 2012; 2013). Küresel 1sınmanın meydana getirdiği iklim değişikliği etkileriyle birlikte artan dünya nüfusunun gelecekte beslenme ve giyinme gereksiniminin sağlanması amaciyla kurağa toleranslı ve daha az su ihtiyac1 bulunan bitki genotiplerinin geliştirilmesi gerektiği bildirilmektedir (Sankar ve ark., 2008). Ülkemizin, Orta Anadolu ve Güneydoğu Anadolu Bölgelerinde hatta son zamanlarda tüm ülke çapında yağış miktarının yetersiz veya düzensiz olması nedeniyle, tarımsal ürünlerin su ihtiyacı gerektiği kadar karşılanamamakta ve bunun sonucu olarak önemli ürün kayıpları meydana gelmektedir. Nohutta, kuraklık stresine karşı yapılabilecek 1slah çalışmalarında; genotiplerin potansiyel durumlarını ayırt etmek için etkili seleksiyon tekniklerinin olmaması, genotiplerin kurağa toleranslıkta genetik çeşitliliği hakkında yetersiz bilgi sahibi olunması ıslah çalışmalarını engelleyici önemli faktörler olarak sıralanmaktadır. Bu çalışma ile değişik nohut genotiplerinin tarla koşullarında kuraklık stresine karşı duyarlılığını saptamak ve stres faktörlerine toleranslılığ1 yüksek genotiplerin belirlenerek, ileride yapılabilecek ıslah çalışmaları ile yüksek verime sahip kurağa toleranslı yeni çeşitler geliştirerek, kuraklık koşullarda nohut üretiminin artırılması hedeflenmiştir. 


\section{MATERYAL ve METOT}

Araştırma, Doğu Akdeniz Tarımsal Araştırma Enstitüsü Araştırma Alanında $\left(35^{\circ} 18^{\prime}\right.$ E, $37^{\circ} 01^{\prime}$ N; 23 $\mathrm{m}$ rakım), Adana 2015-16 yetiştirme sezonunda, tesadüf bloklarında faktöriyel deneme desenine uygun olarak 3 tekrarlamalı olarak yürütülmüştür. Çalışmada, üç farkl yetiştirme koşulunda (Kışlık ekim, Sulamalı Geç Ekim ve Sulamasız Geç Ekim), 30 adet nohut genotipi ve 4 de kontrol çeşidi olmak üzere toplam 34 hat ve çeşit kullanılmıştır. Her parsel $4 \mathrm{~m}$ uzunluğunda, iki sıradan oluşmakta, sıra arası $45 \mathrm{~cm}$ sabit tutularak her sıraya 60 adet tohum gelecek şekilde ekilmiștir. Ekimden önce taban gübresi olarak dekara $3 \mathrm{~kg} \mathrm{~N}$ (azot) ve $6 \mathrm{~kg} \mathrm{P}_{2} \mathrm{O}_{5}$ (fosfor) gübresi tüm deneme alanına verilmiştir. Araştırmada, kışlık ekimler 21 Aralık 2015; Geç ekimler ise 28 Şubat 2016 tarihinde yapılmıștır. Tarla denemelerinde ICARDA'nın uluslararas1 baklagil denemelerinde uygulanan ve Singh vd. (1981) tarafindan belirtilen yöntemlerle; Çiçeklenmeye Kadar Geçen Gün Sayısı (gün), Bakla Bağlamaya Kadar Geçen Gün Sayısı (gün), Bitki Boyu (cm), İlk Bakla Yüksekliği (cm), 100 Tane Ağırlığı (g) ve Tane Verimi $(\mathrm{kg} / \mathrm{da})$ incelenmiştir. Araştırmanın yürütüldüğü yılda en düşük ve yüksek ortalama sıcaklık ile toplam yağış değerleri sirasıyla $8{ }^{\circ} \mathrm{C}$ (Ocak) ve $32{ }^{\circ} \mathrm{C}$ (Haziran); 0 $\mathrm{mm}$ (Temmuz) ve $43.18 \mathrm{~mm}$ (Şubat)'dir (Anonim, 2015-2016). Doğu Akdeniz Tarımsal Araştırma Enstitüsü'nde denemenin yürütüldüğü toprak yapısı killi-tınlı kahverengi alüviyal topraklar sınıfinda olup pH's1 7.43-8,0; tuz içeriği \% 0.23-0.22 ve kireç içeriği ise 12.0- 12.1 arasında değişmektedir (Anonim, 2015).Elde edilen veriler, tesadüf bloklarında faktöriyel deneme desenine göre analiz edilmiştir. İstatistikî analizler ve elde edilecek ortalamaların karşılaştııılmasında, JMP paket programı kullanılmıştır.

\section{BULGULAR, TARTISSMA ve SONUÇ}

Araştırmada incelenen tüm özelliklerde yapılan analiz sonucunda, çeşit, yetiştirme koşulu ve çeşit $\mathrm{x}$ yetiştirme koşulu interaksiyonu önemli bulunmuştur. Farklı yetiştirme koşulları altında nohut genotiplerinde saptanan çiçeklenmeye ve bakla bağlamaya kadar geçen gün sayılarına ve bitki boyu değerlerine ilişkin ortalama değerler ve oluşan gruplar, Çizelge1'de verilmiştir. Farklı yetiştirme koşullarında çiçeklenme süresi 109.3971.78 gün arasında değişmekte olup, kışlık ekim uygulaması anılan özellik bakımından ilk sırada yer alırken, sulamalı geç ekim ve sulamasız geç ekim uygulamaları istatistikî olarak aynı grubu paylaşmışlardır. Kışlık ekimlerde hava sıcaklığının daha düşük olması çıkış süresi ve vejetatif süreyi uzatmış ve sonuçta çiçeklenme süresi de uzamıştır. Aynı çizelgeden izlendiği gibi, nohut çeşitlerinde saptanan çiçeklenme süresi ise 88.33-66.0 gün arasında değişmiş olup en yüksek değer FLIP 01-54 C çeşidinden elde edilmiştir. Kuraklık stresinden kaçınmak için erken çiçeklenebilen nohut genotiplerinin seçilmesi önemli bir seleksiyon kriteridir. Erken çiçeklenebilen ve erken bakla bağlayabilen genotipler, tane doldurmak için hem daha uzun bir süreye sahip olmakta hem de mevcut nemden daha iyi yararlanabilmektedirler. Erken çiçeklenmenin kuraklık ve sıcaklık stresinden kaçmada önemli bir özellik olduğu değişik araştırmalarda da bildirilmektedir (Saxenave ark.,1993; Silim ve Saxena, 1993; Devasirvatham, 2012). Bu durum dikkate alındığında EN 952, FLIP 05-150 C, FLIP 03-42 C, FLIP 03-108 C,FLIP 03-21 C, FLIP 01-24, ENA 8-2 ve EN 1685 nohut genotipleri diğer genotiplerden daha erken çiçeklenmişlerdir. Çizelge1' den izlendiği gibi, çiçeklenme süresi bakımından önemli bulunan çeşit $\mathrm{x}$ yetiştirme koşulu interaksiyonuna ilişkin ortalama değerler, 111.67-56.0 gün arasında değişmiştir. En yüksek çiçeklenme süresi değeri kışlık ekimlerinde ICC 1205 çeşidi dışındaki tüm çeşitlerden elde edilmiştir. En düşük değer ise ICC- 1205 çeşidinin hem sulamalı hem de sulamasız geç ekimlerden elde edilmiştir.

Farklı yetiştirme koşullarında bakla bağlama süresi 119.97-80.41 gün arasında değişmekte olup, kışlık ekim uygulaması anılan özellik bakımından ilk sırada yer almıştır (Çizelge 1). Aynı çizelgeden izlendiği gibi, nohut çeşitlerinde saptanan bakla bağlama süresi 97.6784.44 gün arasında değişmiş ve Azkan çeşidi en yüksek değere sahip olmuştur. Nohut tarımında generatif dönem (çiçeklenme ve bakla bağlama) dış çevre değişikliklerine çok hassas olarak bilinmekte ve bu dönemdeki yüksek sicaklık ve kuraklıklar, tane veriminde önemli düşüşlere neden olmaktadır (Summerfield ve ark.1990; Wang ve ark. 2006). Yaz sıcaklarının aniden başladığı Çukurova bölgesi gibi ekolojilerde bitkilerin erken bakla bağlamaları olgunlaşmaya kadar geçen süreyi uzatmaktadır. Böylece, erken bakla bağlama süresine sahip olan çeşitlerin verim ve tane ağırlı̆ğ da artmaktadır. $\mathrm{Bu}$ durum dikkate alındığında FLIP 05-150 C, EN 1750, F4 09 (X 05 TH 21 16189-12-4), FLIP 01-24 C, FLIP 0342 C,Hasanbey, FLIP 03-108 C, FLIP 03-21 C nohut genotipleri diğer genotiplerden daha erken sürede bakla bağlamışlardır. Çizelge 1'den izlendiği gibi, bakla bağlama süresi bakımından önemli bulunan çeşit $\mathrm{x}$ yetiștirme koşulu interaksiyonuna ilișkin ortalama değerler, 124.0-71.0 gün arasında değişmiş olup, kışlık ekim uygulamasında yer alan tüm çeşitler ilk sıralarda yer almışlardır. En düşük bakla bağlama süresi ise ICC 1205 çeșidinin hem sulamalı hem de sulamasız geç ekiminden elde edilmiştir. Çizelge 1'den izlendiği gibi farklı yetiştirme koşullarında saptanan bitki boyu değerleri 54.51-46.38 cm arasında değişmektedir. Bitki boyu bakımından, kışlık ekim uygulaması en yüksek değere sahip olurken sulamasız geç ekim uygulaması ise en düşük değere sahip olmuştur. Nohut çeşitlerinde saptanan bitki boyu değeri 61.94-39.17 $\mathrm{cm}$ arasında değişmiştir. En yüksek bitki boyu değeri F4 09 (X 05 TH 69-16124-8) genotipinden elde edilirken, FLIP 8759 C, EN 766 ve FLIP 01-24 C genotipleri de ayn grupta yer almıştır. En düşük değer ise ICC 1205 çeşidinden alınmıştır. Önemli bulunan çeşit $\mathrm{x}$ yetiştirme koşulu interaksiyonuna ilişkin ortalama değerler 68.33$33.33 \mathrm{~cm}$ arasında değişmiş̧tir (Çizelge 1). Anılan özellik bakımından kışlık ekim uygulamasında F4 09 (X 05 TH 69-16124-8) çeşidi en yüksek değere sahip olmuştur. 
Çizelge 1. Farklı Yetiştirme Koşulları Altında Nohut Genotiplerinin Çiçeklenme, Bakla Bağlamaya Kadar Geçen Gün Sayılarına ve Bitki Boyuna İlişkin Ortalama Değerler ve Oluşan Gruplar

\begin{tabular}{|c|c|c|c|c|c|c|c|c|c|c|c|c|}
\hline \multirow[t]{2}{*}{ GENOTİPLER } & \multicolumn{4}{|c|}{$\begin{array}{c}\text { Çiçeklenmeye Kadar Geçen } \\
\text { Gün Sayı1 (gün) }\end{array}$} & \multicolumn{4}{|c|}{$\begin{array}{l}\text { Bakla Bağlamaya Kadar } \\
\text { Geçen Gün Sayısı (gün) }\end{array}$} & \multicolumn{4}{|c|}{$\begin{array}{l}\text { Bitki Boyu } \\
(\mathrm{cm})\end{array}$} \\
\hline & $\begin{array}{l}\text { Kışlık } \\
\text { Ekim }\end{array}$ & $\begin{array}{l}\text { Sulamali } \\
\text { Ekim }\end{array}$ & $\begin{array}{l}\text { Sulamas1 } \\
\text { z Ekim }\end{array}$ & ORT. & $\begin{array}{l}\text { Kışlik } \\
\text { Ekim }\end{array}$ & $\begin{array}{l}\text { Sulama } \\
l_{1} \\
\text { Ekim }\end{array}$ & $\begin{array}{l}\text { Sulama } \\
\text { S1z } \\
\text { Ekim }\end{array}$ & ORT. & $\begin{array}{l}\text { Kişlik } \\
\text { Ekim }\end{array}$ & $\begin{array}{l}\text { Sulamalı } \\
\text { Ekim }\end{array}$ & $\begin{array}{l}\text { Sulamas1 } \\
\text { z Ekim }\end{array}$ & ORT. \\
\hline Aksu & 111.67 & 74.33 & 73.00 & \begin{tabular}{|l|}
86.33 \\
\end{tabular} & 118.00 & 84.00 & 81.33 & 94.44 & 49.17 & 45.83 & 48.83 & 47.94 \\
\hline Arda & 111.67 & 75.33 & 75.00 & 87.33 & 119.67 & 83.00 & 85.00 & 95.89 & 52.50 & 50.00 & 49.17 & 50.56 \\
\hline Azkan & 111.33 & 76.00 & 73.67 & 87.00 & 123.00 & 86.67 & 83.33 & 97.67 & 51.67 & 46.67 & 41.67 & 46.67 \\
\hline Çağatay & 109.67 & 71.33 & 74.33 & 85.11 & 120.67 & 83.00 & 82.00 & 95.22 & 55.83 & 53.33 & 46.67 & 51.94 \\
\hline Çakır & 111.67 & 74.33 & 75.67 & 87.22 & 120.67 & 84.33 & 81.33 & 95.44 & 54.17 & 47.50 & 48.33 & 50.00 \\
\hline Dikbaş & 111.33 & 72.67 & 74.33 & 86.11 & 123.33 & 83.00 & 79.00 & 95.11 & 51.67 & 43.33 & 33.33 & 42.78 \\
\hline EN 1685 & 108.67 & 73.00 & 69.67 & 83.78 & 119.67 & 83.33 & 81.33 & 94.78 & 52.50 & 45.83 & 42.50 & 46.94 \\
\hline EN 1750 & 110.67 & 71.00 & 70.33 & 84.00 & 120.33 & 81.67 & 75.67 & 92.56 & 51.67 & 48.33 & 42.50 & 47.50 \\
\hline EN 766 & 111.33 & 73.67 & 74.00 & 86.33 & 121.67 & 81.67 & 80.00 & 94.44 & 62.50 & 56.67 & 58.33 & 59.17 \\
\hline EN 808 & 109.67 & 75.00 & 74.00 & 86.22 & 121.67 & 83.67 & 81.33 & 95.56 & 50.00 & 46.67 & 41.83 & 46.17 \\
\hline EN 952 & 109.00 & 71.67 & 69.67 & 83.44 & 120.67 & 82.00 & 82.00 & 94.89 & 56.67 & 49.83 & 50.00 & 52.17 \\
\hline ENA $144-10$ & 110.67 & 71.67 & 71.00 & 84.44 & 118.33 & 81.67 & 81.67 & 93.89 & 57.50 & 54.17 & 48.33 & 53.33 \\
\hline ENA 8-2 & 109.00 & 69.33 & 71.00 & 83.11 & 121.00 & 79.33 & 79.67 & 93.33 & 55.83 & 49.17 & 49.17 & 51.39 \\
\hline $\begin{array}{l}\text { TH } 21 \text { 16189-12- } \\
4\end{array}$ & 109.00 & 71.00 & 72.33 & 84.11 & 116.67 & 81.00 & 79.67 & 92.44 & 59.17 & 53.33 & 49.17 & 53.89 \\
\hline TH 69-16124-8 & 110.00 & 75.33 & 73.00 & 86.11 & 122.00 & 84.00 & 84.00 & 96.67 & 68.33 & 56.67 & 60.83 & 61.94 \\
\hline $\begin{array}{l}\text { TH 80-16105-31- } \\
2\end{array}$ & 110.67 & 75.67 & 74.33 & 86.89 & 123.00 & 80.67 & 81.00 & 94.89 & 57.50 & 45.00 & 48.33 & 50.28 \\
\hline FLIP 01-24 C & 110.33 & 70.33 & 70.33 & 83.67 & 118.33 & 79.00 & 78.33 & 91.89 & 62.50 & 56.33 & 55.00 & 57.94 \\
\hline FLIP 01-39 C & 110.67 & 72.33 & 76.33 & 86.44 & 121.00 & 82.33 & 81.00 & 94.78 & 52.50 & 54.17 & 45.00 & 50.56 \\
\hline FLIP 01-54 C & 111.00 & 77.67 & 76.33 & 88.33 & 121.33 & 83.67 & 84.00 & 96.33 & 48.33 & 46.67 & 45.00 & 46.67 \\
\hline FLIP 03-108 C & 108.67 & 67.67 & 69.67 & 82.00 & 117.00 & 78.33 & 77.67 & 91.00 & 56.67 & 52.50 & 47.50 & 52.22 \\
\hline FLIP 03-126 C & 110.33 & 74.33 & 74.33 & 86.33 & 122.33 & 83.33 & 84.00 & 96.56 & 52.50 & 44.17 & 44.17 & 46.94 \\
\hline FLIP 03-21 C & 109.00 & 67.33 & 68.33 & 81.56 & 116.67 & 78.33 & 76.33 & 90.44 & 55.83 & 52.50 & 50.00 & 52.78 \\
\hline FLIP 03-28 C & 111.33 & 70.33 & 72.33 & 84.67 & 120.67 & 80.67 & 78.33 & 93.22 & 46.67 & 50.83 & 44.17 & 47.22 \\
\hline FLIP 03-42 C & 109.00 & 69.00 & 68.33 & 82.11 & 117.00 & 78.33 & 78.33 & 91.22 & 54.17 & 55.00 & 46.37 & 51.84 \\
\hline FLIP 05-150 C & 109.67 & 70.00 & 70.33 & 83.33 & 120.00 & 81.67 & 76.33 & 92.67 & 55.83 & 48.33 & 49.17 & 51.11 \\
\hline FLIP 05-170 C & 109.00 & 73.00 & 72.33 & 84.78 & 120.67 & 81.67 & 81.00 & 94.44 & 51.67 & 62.60 & 39.33 & 51.20 \\
\hline FLIP 87-59 C & 110.00 & 76.33 & 74.33 & 86.89 & 124.00 & 82.67 & 83.67 & 96.78 & 66.67 & 59.17 & 56.67 & 60.83 \\
\hline Hasanbey & 109.00 & 73.67 & 70.67 & 84.44 & 117.00 & 77.00 & 79.33 & 91.11 & 54.17 & 50.83 & 42.50 & 49.17 \\
\hline ICC 1205 & 86.00 & 56.00 & 56.00 & 66.00 & 111.33 & 71.00 & 71.00 & 84.44 & 45.00 & 35.83 & 36.67 & 39.17 \\
\hline ICC 4567 & 108.33 & 69.67 & 67.67 & 81.89 & 117.00 & 81.67 & 81.00 & 93.22 & 53.33 & 45.83 & 37.50 & 45.56 \\
\hline ILC 8617 & 108.67 & 67.00 & 67.00 & 80.89 & 117.00 & 77.67 & 77.67 & 90.78 & 55.00 & 47.50 & 44.17 & 48.89 \\
\hline İnci & 110.67 & 75.33 & 76.00 & 87.33 & 123.00 & 84.00 & 83.67 & 96.89 & 52.50 & 49.17 & 47.50 & 49.72 \\
\hline İzmir-92 & 110.33 & 73.67 & 70.67 & 84.89 & 121.33 & 82.67 & 80.00 & 94.67 & 60.00 & 52.50 & 49.17 & 53.89 \\
\hline Seçkin & 111.33 & 75.33 & 74.33 & 87.00 & 123.00 & 84.00 & 84.00 & 97.00 & 43.33 & 47.33 & 38.00 & 42.89 \\
\hline ORTALAMA & 109.39 & 72.07 & 71.78 & & 119.97 & 81.50 & 80.41 & & 54.51 & 50.11 & 46.38 & \\
\hline CV (\%) & \multicolumn{4}{|c|}{2.19} & \multicolumn{4}{|c|}{2.11} & \multicolumn{4}{|c|}{7.94} \\
\hline LSD (0.05) & \multicolumn{3}{|c|}{ Ç X YK: 6.63} & & $\begin{array}{c}\text { YK:0.6 } \\
3\end{array}$ & $\begin{array}{r}\text { Ç X } \\
7 .\end{array}$ & YK: & $: 3.5$ & $\begin{array}{l}\text { YK: } \\
1.32 \\
\end{array}$ & Ç X & 31 & Ç: 7.26 \\
\hline
\end{tabular}

Çeşit. Ç; Yetiştirme Koşulları YK; Çeşit x Yetiştirme Koşulları İnteraksiyonu; Ç X YK

En düşük bitki boyu değeri ise sulamasız geç ekim uygulamasında Dikbaş çeşidinden elde edilmiştir. Farklı yetiştirme koşulları altında nohut genotiplerinde saptanan ilk bakla yüksekliği, yüz tane ağırlığı ve tane verimi değerlerine ilişkin ortalama değerler ve oluşan gruplar, Çizelge2'de verilmiştir. Farklı yetiştirme koşullarında saptanan ilk bakla yüksekliği değeri 28.95$23.68 \mathrm{~cm}$ arasında değişmekte olup, kışlık ekim uygulaması anılan özellik bakımından ilk sırada yer almaktadır (Çizelge 2). Nohut çeşitlerinde saptanan ilk bakla yüksekliği değerleri 32.78-16.56 cm arasında değişmiştir. Anılan özellik bakımından, FLIP 87-59 C, EN 766, F4 09 (X 05 TH 69-16124-8), İzmir-92, EN 952, ENA 144-10, F4 09 (X 05 TH 21 16189-12-4),
FLIP 01-39 C, FLIP 03-126 C ve FLIP 03-21 C genotipleri ilk sıralarda yer almıştır. En düşük değer ise ICC 1205 çeşidinden alınmıştır. Makineli hasatta hasat kayıplarını azaltabilmek için ilk baklalarını yüksekten bağlayabilen çeşitler tercih edilmektedir. Çeşit $\mathrm{x}$ yetiştirme koşuluna ilişkin ortalama değerler, 34.17$14.17 \mathrm{~cm}$ arasında değişmiştir (Çizelge 2). Anılan özellik bakımından kışlık ekim uygulamasında F4 09 (X 05 TH 69-16124-8) çeşidi en yüksek değere sahip olmuştur. En düşük ilk bakla yüksekliği değeri ise ILC 8617 çeşidinin sulamasız geç ekiminden elde edilmiştir. Çizelge2'den izlendiği gibi farklı yetiştirme koşullarında saptanan yüz tane ağırlığı değeri 43.64$36.07 \mathrm{~g}$ arasında değişmekte olup kışlık ekim 
uygulaması anılan özellik bakımından ilk sırada yer almıştır. Aynı çizelgeden izlendiği gibi, nohut çeşitlerinde saptanan yüz tane ağırlığı değeri, 48.68$12.22 \mathrm{~g}$ arasında değişmiştir. Yüz tane ağırlığı bakımından F4 09 (X 05 TH 21 16189-12-4) çeşidi en yüksek değere sahip olmuştur. Bu çeşidi, EN 1685, FLIP 05-170 C, Çağatay, F4 09 (X 05 TH 80-16105-312), F4 09 (X 05 TH 69-16124-8), EN 952, EN 766, FLIP 03-42 C, ENA 8-2, EN 1750, Aksu, FLIP 01-24 C, Çakır ve Dikbaş çeşitleri izlemiştir.

Çizelge 2. Farklı Yetiştirme Koşulları Altında Nohut Genotiplerinin İlk Bakla Yüksekliği, Yüz Tane Ağırlı̆ı ve Tane Verimi 'ne İlişkin Ortalama Değerler ve Oluşan Gruplar

\begin{tabular}{|c|c|c|c|c|c|c|c|c|c|c|c|c|}
\hline \multirow[t]{2}{*}{ GENOTİPLER } & \multicolumn{4}{|c|}{ İlk Bakla Yüksekliği (cm) } & \multicolumn{4}{|c|}{ Yüz Tane Ağırlığı $(\mathrm{g})$} & \multicolumn{4}{|c|}{ Tane Verimi $\left(\mathrm{kg} \mathrm{da}^{-1}\right)$} \\
\hline & $\begin{array}{l}\text { Kışlik } \\
\text { Ekim }\end{array}$ & $\begin{array}{l}\text { Sulama } \\
\text { l1 } \\
\text { Ekim }\end{array}$ & $\begin{array}{l}\text { Sulama } \\
\text { siz } \\
\text { Ekim }\end{array}$ & ORT. & $\begin{array}{l}\text { Kışlık } \\
\text { Ekim }\end{array}$ & $\begin{array}{l}\text { Sulamal1 } \\
\text { Ekim }\end{array}$ & $\begin{array}{l}\text { Sulama } \\
\text { siz } \\
\text { Ekim }\end{array}$ & ORT. & $\begin{array}{l}\text { Kişlik } \\
\text { Ekim }\end{array}$ & $\begin{array}{l}\text { Sulamalı } \\
\text { Ekim }\end{array}$ & \begin{tabular}{|l|} 
Sulama \\
s1z \\
Ekim
\end{tabular} & ORT. \\
\hline Aksu & 33.0 & 26.67 & 22.50 & 27.39 & 44.83 & 36.97 & 43.03 & 41.61 & 291.43 & 85.30 & 77.60 & 151.44 \\
\hline Arda & 25.0 & 30.83 & 28.33 & 28.06 & 43.43 & 37.90 & 32.83 & 38.06 & 291.90 & 97.23 & 71.43 & 153.52 \\
\hline Azkan & 28.33 & 27.5 & 22.5 & 26.11 & 45.10 & 37.70 & 36.57 & 39.79 & 236.17 & 49.53 & 38.77 & 108.16 \\
\hline Çağatay & 29.17 & 27.5 & 24.17 & 26.95 & 48.30 & 42.40 & 40.57 & 43.76 & 135.17 & 73.03 & 48.47 & 85.56 \\
\hline Çakır & 24.83 & 24.17 & 25.0 & 24.67 & 47.10 & 39.07 & 38.03 & 41.40 & 203.30 & 92.10 & 77.40 & 124.27 \\
\hline Dikbaş & 22.5 & 20.83 & 20.83 & 21.39 & 48.20 & 36.67 & 39.00 & 41.29 & 118.77 & 52.10 & 37.97 & 69.61 \\
\hline EN 1685 & 27.5 & 27.5 & 21.67 & 25.56 & 49.93 & 43.20 & 40.20 & 44.44 & 163.37 & 78.13 & 52.97 & 98.16 \\
\hline EN 1750 & 26.67 & 25.0 & 24.17 & 25.28 & 48.03 & 39.37 & 38.07 & 41.82 & 135.90 & 52.67 & 28.17 & 72.24 \\
\hline EN 766 & 33.33 & 32.5 & 32.5 & 32.78 & 47.67 & 40.03 & 40.00 & 42.57 & 196.53 & 60.20 & 48.57 & 101.77 \\
\hline EN 808 & 26.67 & 24.17 & 23.33 & 24.72 & 46.20 & 38.43 & 38.00 & 40.88 & 157.73 & 76.23 & 55.93 & 96.63 \\
\hline EN 952 & 29.17 & 27.5 & 23.17 & 26.61 & 48.10 & 39.37 & 40.33 & 42.60 & 144.93 & 72.47 & 54.13 & 90.51 \\
\hline ENA $144-10$ & 30.0 & 29.17 & 26.0 & 28.39 & 45.17 & 37.43 & 36.23 & 39.61 & 161.60 & 79.93 & 53.83 & 98.46 \\
\hline ENA 8-2 & 28.33 & 25.0 & 22.17 & 25.17 & 46.53 & 40.07 & 39.63 & 42.08 & 176.47 & 73.60 & 58.97 & 103.01 \\
\hline $\begin{array}{l}\text { TH } 21 \text { 16189-12- } \\
4\end{array}$ & 30.83 & 27.5 & 22.3 & 26.89 & 53.73 & 47.00 & 45.30 & 48.68 & 235.67 & 121.10 & 82.80 & 146.52 \\
\hline TH 69-16124-8 & 34.17 & 31.67 & 24.17 & 30.0 & 52.37 & 37.73 & 38.10 & 42.73 & 156.70 & 33.53 & 26.10 & 72.11 \\
\hline $\begin{array}{l}\text { TH 80-16105-31- } \\
2\end{array}$ & 27.5 & 26.17 & 21.67 & 25.11 & 50.50 & 40.67 & 39.43 & 43.53 & 128.40 & 78.77 & 45.90 & 84.36 \\
\hline FLIP 01-24 C & 30.83 & 28.33 & 24.17 & 27.78 & 46.70 & 39.50 & 38.33 & 41.51 & 203.23 & 84.73 & 39.90 & 109.29 \\
\hline FLIP 01-39 C & 30.83 & 28.33 & 25.0 & 28.06 & 38.90 & 32.90 & 35.07 & 35.62 & 195.70 & 98.10 & 56.43 & 116.74 \\
\hline FLIP 01-54 C & 27.5 & 24.17 & 20.83 & 24.17 & 37.43 & 31.50 & 29.73 & 32.89 & 162.07 & 71.07 & 39.90 & 91.01 \\
\hline FLIP 03-108 C & 30.0 & 27.5 & 26.67 & 28.06 & 45.00 & 37.60 & 35.57 & 39.39 & 258.57 & 104.07 & 80.03 & 147.56 \\
\hline FLIP 03-126 C & 31.17 & 28.83 & 26.67 & \begin{tabular}{|l|}
28.89 \\
\end{tabular} & 44.40 & 36.93 & 35.70 & 39.01 & 189.37 & 85.83 & 51.23 & 108.81 \\
\hline FLIP 03-21 C & 30.83 & 28.5 & 24.17 & 27.83 & 46.13 & 37.50 & 37.60 & 40.41 & 211.10 & 114.33 & 88.67 & 138.03 \\
\hline FLIP 03-28 C & 29.17 & 25.83 & 19.17 & 24.72 & 42.83 & 36.23 & 33.37 & 37.48 & 243.30 & 108.03 & 50.93 & 134.09 \\
\hline FLIP 03-42 C & 30.0 & 28.33 & 22.5 & 26.94 & 48.17 & 39.87 & 39.03 & 42.36 & 232.87 & 108.30 & 73.60 & 138.26 \\
\hline FLIP 05-150 C & 31.83 & 27.5 & 23.33 & 27.56 & 42.17 & 36.43 & 34.27 & 37.62 & 243.07 & 97.23 & 72.37 & 137.56 \\
\hline FLIP 05-170 C & 31.83 & 28.33 & 21.67 & 27.28 & 47.00 & 42.53 & 42.67 & 44.07 & 250.03 & 97.23 & 62.47 & 136.58 \\
\hline FLIP 87-59 C & 33.33 & 32.5 & 28.33 & 31.39 & 33.87 & 26.37 & 27.80 & 29.34 & 265.53 & 94.43 & 82.53 & 147.50 \\
\hline Hasanbey & 30.83 & 27.5 & 25.0 & \begin{tabular}{|l|}
27.78 \\
\end{tabular} & 45.60 & 37.40 & 36.93 & 39.98 & 270.37 & 99.20 & 72.30 & 147.29 \\
\hline ICC 1205 & 20.0 & 15.5 & 14.17 & 16.56 & 13.17 & 11.80 & 11.70 & 12.22 & 154.23 & 86.30 & 79.40 & 106.64 \\
\hline ICC 4567 & 25.0 & 25.0 & 20.83 & 23.61 & 31.63 & 28.30 & 28.97 & 29.63 & 126.70 & 47.57 & 39.60 & 71.29 \\
\hline ILC 8617 & 25.0 & 25.0 & 25.0 & 25.0 & 32.83 & 30.40 & 29.43 & 30.89 & 143.57 & 91.67 & 62.00 & 99.08 \\
\hline İnci & 28.3 & 24.17 & 21.5 & 24.67 & 37.53 & 31.90 & 32.33 & 33.92 & 334.47 & 150.67 & 90.90 & 192.01 \\
\hline İzmir-92 & 31.67 & 30.0 & 28.33 & 30.0 & 42.73 & 37.50 & 36.97 & 39.07 & 121.50 & 79.60 & 60.03 & 87.04 \\
\hline Seçkin & 29.17 & 27.5 & 23.33 & 26.67 & 42.43 & 34.80 & 35.50 & 37.58 & 108.83 & 95.63 & 53.63 & 86.03 \\
\hline ORTALAMA & 28.95 & 26.96 & 23.68 & & 433.64 & 36.57 & 36.07 & & 195.55 & 85.00 & 59.26 & \\
\hline $\mathrm{CV}(\%)$ & \multicolumn{4}{|c|}{9.69} & \multicolumn{4}{|c|}{4.95} & \multicolumn{4}{|c|}{13.71} \\
\hline LSD (0.05) & $\begin{array}{l}\mathrm{YK}: \\
0.85\end{array}$ & $\begin{array}{l}\text { ÇX YK } \\
9.22\end{array}$ & & t & $\begin{array}{l}\text { YK: } \\
0.61\end{array}$ & $\begin{array}{l}\text { Ç X YK } \\
6.89\end{array}$ & & 0.4 & YK: & $\begin{array}{l}\text { Ç X YK } \\
55.67\end{array}$ & & $\begin{array}{l}\text { Ç: } \\
28.25\end{array}$ \\
\hline
\end{tabular}

Çeşit. Ç; Yetiştirme Koşulları YK; Çeşit x Yetiştirme Koşulları İnteraksiyonu; Ç X YK

Araştırmada incelenen çeşitler içerisinden yüz tane ağırlı̆̆ yüksek olan çeşitlerin seçilmesi, iri taneli yeni çeşitlerin geliştirilebilmesi için önemli olacaktır. Böylece, ileride yapılacak ıslah çalışmalarında bu nohut hatlarının kullanılması ticari bakımdan önemli bir kriter olan tane iriliğini arttırarak yeni geliştirilecek çeşitlerin iç ve dış pazardaki talebini de arttıracaktır. Önemli bulunan çeşit $\mathrm{x}$ yetiştirme koşuluna ilişkin ortalama değerler, ise 53.73-11.7 g arasında değişmiştir
(Çizelge2). Anılan özellik bakımından kışlık ekim uygulamasinda yer alan F4 09 (X 05 TH 21 16189-124) çeşidi ilk grupta yer almıştır. En düşük değer ise ICC 1205 (sıcağa toleranslı) kontrol çeşidinin sulamasız geç ekiminden elde edilmiştir.

Farklı yetiştirme koşullarında saptanan tane verimi değerleri, $192.55-59.26 \mathrm{~kg} / \mathrm{da}$ arasında değişmekte olup, kışlık ekim uygulaması anılan özellik bakımından ilk sırada yer almaktadır (Çizelge 2). Kışlık ekim 
uygulamasında yer alan bitkilerin vejetasyon süresinin daha uzun olması ve buna bağlı olarak kış yağışlarından daha fazla yaralanması, tane verimine olumlu yansımıştır. Aynı çizelgeden izlendiği gibi nohut çeşitlerinde saptanan tane verimi değerleri 192.01-69.61 $\mathrm{kg} / \mathrm{da}$ arasında değişmiştir. Anılan özellik bakımından, en yüksek değer, İnci çeşidinden alınmıştır. Kurağa toleranslı FLIP 87-59 C çeşidi ise İnci çeşidinden daha düşük tane verimi değerine sahip olmakla birlikte Arda, Aksu, FLIP 03-108 C, Hasanbey, F4 09 (X 05 TH 21 16189-12-4), FLIP 03-42 C, FLIP 03-21 C, FLIP 05150 C, FLIP 05-170 C ve FLIP 03-28 C çeşitleri ile aynı grupta yer almışlardır. En düşük tane verimi değeri ise Dikbaş çeşidinden elde edilmiştir. Araştırmada, kurağa toleranslı kontrol çeşidin tane verimi kışlık ekimlerde $265.53 \mathrm{~kg} / \mathrm{da}$, sulamasız geç ekimlerde ise 82.53 $\mathrm{kg} / \mathrm{da}$ 'dır. Tane verimi kontrol çeşitte \% 31.08, azalma göstermiştir. Kuraklık stresi bakımından Çağatay, Çakır, EN 808, EN 952, ENA 144-10, ENA 8-2, F4 09 (X 05 TH 21 16189-12-4), F4 09 (X 05 TH 80-16105-31-2), FLIP 03-21 C, İzmir-92 ve Seçkin çeşitlerinin verim azalması ise kontrol çeşitten daha az olmuştur. Çizelge2'den izlendiği gibi, tane verimi bakımından önemli bulunan çeşit $\mathrm{x}$ yetiştirme koşulu interaksiyonuna ilişkin ortalama değerler, 334.47-26.10 $\mathrm{kg} / \mathrm{da}$ arasında değişmiştir. Anılan özellik bakımından en yüksek tane verimi değeri kışlık ekim uygulamasında İnci çeşidinden alınırken bunu Arda ve Aksu çeşitleri izlemiş olup aynı grubu paylaşmışlardır. En düşük tane verimi ise sulamasız geç ekim uygulamasında F4 09 (X 05 TH 69-16124-8) çeşidinden elde edilmiştir. Sonuç olarak araştırmada yer alan Aksu, Arda, Çakır, İnci ve Hasanbey çeşitleri nohut tarımının yapıldığı kurak bölgelerde önerilebilmektedir. EN 952, ENA 144-10, ENA 8-2, F4 09 (X 05 TH 21 16189-12-4), F4 09 (X 05 TH 80-16105-31-2) FLIP 03-21 C, EN 766, FLIP 03$108 \mathrm{C}$, ve FLIP 05-150 C hatları ileride yapılacak kuraklık stres çalışmalarında değerlendirilebilir.

\section{TEŞEKKÜR}

$\mathrm{Bu}$ çalışma, Türkiye Bilimsel ve Teknolojik Araştırma Kurumu (TUBITAK) tarafindan desteklenmiştir (Project No. 214 O 049). Katkılarından dolayı teşekkür ederiz.

\section{KAYNAKLAR}

Anonim 2015-2016. Adana Meteoroloji Bölge Müdürlüğü Aylık Hava Raporları.

Anonim 2015. Ç.Ü. Zir. Fak. Toprak Bölümü Laboratuarları Analiz Sonuçları, Adana
Devasirvatham V 2012. The Basis of Chickpea Heat Tolerance under Semiarid Environments, a thesis submitted for the degree of Doctor of Philosophy Faculty of Agriculture and Environment the University of Sydney. 160 pages

Sankar B, Abdul Jaleel C, Manivannan PA, Kishorekumar R, Somasundaram R, Panneerselvan, R 2008. "Relative Efficiency of Water Use in Five Varieties of Abelmoschusesculentus(L.) Moench. Under Water Limited Conditions".Biointerfaces. 62, 125-129

Saxena NP, Krishnamurthy L, Johansen C 1993. Registration to a drought resistant chickpea germplasm (En.) Crop Sci., 33(6): 14-24.

Silim SN, Saxena MC 1993. Adaptation of spring sowed chickpea to Mediterranean basin. II. factors influencing drought. Field Crop Res., 34(2): 137-146.

Singh KB, Hawtin GC, Nene YL, Reddy MV 1981. Resistance in Chickpea to Ascochyta blight. Plant Disease 65, 586-587.

Summerfield RJ, Hadley P, Roberts EH, Minchin FR, Rawsthrone S 1990. Sensitivity of Chickpea (CicerarietinumL.) to Hot Temperatures during the Reproductive Period". Experimental Agriculture20, 77-93.

Şehirali S 1988.Yemeklik Tane Baklagiller. Ankara Üniversitesi Ziraat Fakültesi Yayınları, 1089, Ders Kitab1.Sayfa 314-345.

Wang J, Gan YT, Clarke F, Mc Donald CL 2006. Response of Chickpea Yield to High Temperature Stress during Reproductive Development.Crop Sci. 46, 2171-2178.

Yücel Özveren D, Ton A, Anlarsal AE 2012. Determining The Yield and Yield Components of Some Winter Chickpea (Cicerarietinum L.) Genotypes in Mediterranean Climate Conditions. Inter. Symposium For Agriculture And Food XXXVII Faculty-Economy Meeting Macedonian Symposium For Viticulture And Wine Production VII Symposium For Vegetable And Flower Production, December, 12-14 Skopje.

Yücel C, Yücel D, Ortaş İ, Islam KR 2013. İklim Değişikliklerinin.Tarım Üzerine Olası Etkileri, Alınması.Düşünülen Tarımsal Önlemler. Türkiye X. Tarla.Bitkileri.Kongresi, 10-13 Eylül 2013 Konya 